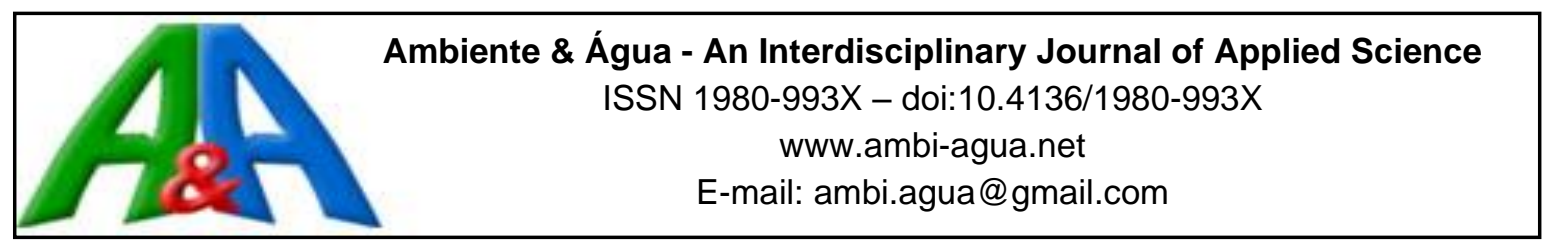

\title{
Heavy rainfall maps in Brazil to 5 year return period
}

\author{
ARTICLES doi:10.4136/ambi-agua.2403
}

Received: 10 Apr. 2019; Accepted: 06 Aug. 2019

\author{
Gabriela Rezende de Souza ${ }^{*}$; ; Italoema Pinheiro Bello ${ }^{1}$; \\ Luiz Fernando Coutinho de Oliveira ${ }^{1}$; Flavia Vilela Corrêa ${ }^{1}$
}

\author{
${ }^{1}$ Departamento de Recursos Hídricos e Saneamento (DRS), Universidade Federal de Lavras (UFLA), Câmpus \\ Universitário, Caixa Postal 3037, CEP 37200-000, Lavras, MG, Brazil. E-mail: italoemapb@ hotmail.com, \\ coutinho@ufla.br, flavia-vilela-correa@hotmail.com \\ *Corresponding author. E-mail: rezendesgabriela@gmail.com
}

\begin{abstract}
This study created thematic heavy rainfall maps for Brazil, with durations of 5-, 30-, 60and 120 minutes and 5 years of return period (T). The intensity-duration-frequency (IDF) relationships used were compiled from studies found in the literature (798 locations) and derived for 4411 rainfall gauges available in the Hidroweb information system, totaling 5209 rainfall data collected. To derive IDF relationships, Gumbel's probability distributions were used, with parameters estimated by the method of moments. Distribution adequacy was verified by the Kolmogorov-Smirnov test. Rainfall-intensity values obtained by IDF relationships were spatialized in Geographic Information Systems, allowing elaboration of the thematic maps. Thematic maps enable obtain rainfall intensities for places without rain gauge data and/or precarious time-series data. Therefore, these maps are a great tool for the design of hydraulic structures related to urban and rural micro-drainage.
\end{abstract}

Keywords: Gumbel frequency distribution, intensity-duration-frequency relationships, kriging.

\section{Mapas de Chuvas Intensas no Brasil com Tempo de Retorno de 5 Anos}

\section{RESUMO}

Este estudo tem como objetivo criar mapas temáticos de chuvas intensas para o Brasil para durações de 5, 30, 60 e 120 minutos e período de retorno de 5 anos (T). As relações intensidadeduração-frequência (IDF) utilizadas foram compiladas a partir de estudos encontrados na literatura (798 locais) e estimadas para 4411 estações pluviométricos disponíveis no sistema de informações Hidroweb, totalizando dados de 5209 estações. Para a derivação das relações IDF, se utilizou a distribuição de probabilidade de Gumbel com parâmetros estimados pelo método dos momentos e aderência da distribuição verificada pelo teste de Kolmogorov-Smirnov. Os valores das intensidades de precipitação obtidos pelas relações IDF foram espacializados em um Sistema de Informações Geográficas, permitindo a criação de mapas temáticos. Os mapas temáticos permitem obter intensidades de precipitação para locais sem dados de pluviometria e/ou dados de séries temporais precários. Portanto, esses mapas são uma ótima ferramenta para o projeto de construções hidráulicas relacionadas à drenagem urbana e rural.

Palavras-chave: distribuição de frequência de Gumbel, krigagem, relações intensidade-duraçãofrequência.

This is an Open Access article distributed under the terms of the Creative Commons Attribution License, which permits unrestricted use, distribution, and reproduction in any medium, provided the original work is properly cited. 


\section{INTRODUCTION}

Heavy or extreme rainfalls are those that present large rain depth in short time intervals, which can cause damage both in urban and agricultural areas, such as flooding, soil erosion, nutrient loss and water body silting (Campos et al., 2014).

Studies related to heavy rainfall are of great importance to the knowledge of hydrological watersheds behavior for flood management. Maximum rainfall intensities are used to design hydraulic structures, such as agricultural and urban flooding control measures and water storage and supply for irrigation, industry, domestic and/or animals (Caldeira et al., 2015; Silva Miranda et al., 2017).

For hydraulic structure design, a rainfall intensity is always associated with a duration and a certain risk of it being equaled or exceeded, defined by the return period (T). Therefore, it is necessary to know the intensity-duration-frequency relation (IDF) of heavy rain, allowing practical and adequate rainfall data use (Xavier et al., 2014). In Brazil, pioneering studies were developed by Pfafstetter (1957) and Denardin and Freitas (1982), in which were adjusted the IDF relationships of 80 gauging stations distributed throughout the country.

Among the most recent studies related to IDF relationships derivation in Brazil are in the states of Goiás and Federal District (Oliveira et al., 2005); Mato Grosso do Sul (Santos et al., 2009); Mato Grosso (Oliveira et al., 2011); Pará (Souza et al., 2012); Sergipe (Aragão et al., 2013); Piauí and Maranhão (Campos et al., 2014; 2015); Paraíba (Campos et al., 2017).

Heavy rainfall modeling using IDF relationships can be performed with data from rain gauges and recording gauges that are able to provide continuous records of rainfall. Souza et al. (2012) emphasize that the IDF relationship determination presents great difficulties due to the low number of recording gauges and short periods of observation available. Another complication is the exhaustive tabulation, analysis and interpretation work of many data from recording gauges (Silva and Oliveira, 2017).

An alternative to construct IDF curves is to use methodologies that permit the expression of IDF relationships from time-series of annual maximum rainfall events. These data are easily obtained from rain gauges (Aragão et al., 2013). The estimate of precipitation intensities associated with the occurrence frequencies can be obtained by applying probability distributions (Franco et al., 2018). The Gumbel's distribution has been shown adequate to describe extreme events, mainly maximum precipitations (Penner and Lima, 2016).

Even so, there are places lacking rainfall data records. In these cases, one of the techniques employed is the rainfall spatial interpolation. Spatial interpolation is performed in Geographic Information Systems (GIS) environments by means of interpolation methods, which generate distributed surfaces of a given variable from point data (Righi and Basso, 2016).

According to Almeida (2017), the interpolators can be divided into deterministic and geostatistical, these last being applied more in spatial interpolation of heavy rainfall (Mello et al., 2013; Louvet et al., 2016). As reported by Carvalho et al. (2009), the geostatistical kriging interpolator has the capacity to produce better estimates, since it is based on two premises: no biased estimator and minimum estimate variance. In addition, random errors associated with spatial dependence can be reduced (Bachir et al., 2016).

In view of the above, this study aimed to estimate the IDF relationships of gauge stations in the Brazilian territory in order to generate thematic maps of heavy rainfalls of 5 years return period that are important to the design of micro-drainage structures.

\section{MATERIALS AND METHODS}

There are 5209 rain data stations in Brazil. Of these, 798 stations are equipped with recording gauges and the IDF relationships are available in the literature. For the other 4411

Rev. Ambient. Água vol. 14 n. 5, e2403 - Taubaté 2019 
rain gauge stations, the IDF curves were derived using the method of least squares.

Gauge stations that presented at least 15 years of daily observations were selected in the information system Hidroweb of Agência Nacional das Águas (National Water Agency), and the months missing rain data in the historical series were not considered. Then the annual maximum rainfall time-series were elaborated for each station. The maximum rainfall associated with return periods of 2-, 5-, 10-, 20-, 50- and 100 years were estimated by the Gumbel's distribution, since this probability distribution is applied to analyze maximum rainfall frequencies (Mello and Silva, 2005). The Gumbel's distribution parameters were adjusted by the method of moments and theirs adequacy were verified by the Kolmogorov-Smirnov test to a $5 \%$ significance level.

Subsequently, through the methodology proposed by DAEE and CETESB (1980) were obtained the heavy rainfall of 5-, 10-, 15-, 20-, 25- and 30 minutes durations, as well as 1-, 6-, 8-, 10-, 12- and 24 hours durations, associated with each return period. In this methodology, a rainfall depth of lower duration time is estimated by multiplying a rainfall depth of higher duration by a derivation factor (Equation 1 ). The derivation factor values proposed by DAEECETESB are: $\mathrm{h}_{24 \mathrm{~h}} / \mathrm{h}_{\text {daily }}=1.14 ; \mathrm{h}_{12 \mathrm{~h}} / \mathrm{h}_{24 \mathrm{~h}}=0.85 ; \mathrm{h}_{10 \mathrm{~h}} / \mathrm{h}_{24 \mathrm{~h}}=0.82 ; \mathrm{h}_{8 \mathrm{~h}} / \mathrm{h}_{24 \mathrm{~h}}=0.78 ; \mathrm{h}_{6 \mathrm{~h}} / \mathrm{h}_{24 \mathrm{~h}}=0.72 ;$ $\mathrm{h}_{1 \mathrm{~h}} / \mathrm{h}_{24 \mathrm{~h}}=0.42 ; \mathrm{h}_{30 \min } / \mathrm{h}_{1 \mathrm{~h}}=0.74 ; \mathrm{h}_{25 \min } / \mathrm{h}_{30 \min }=0.91 ; \mathrm{h}_{20 \min } / \mathrm{h}_{30 \min }=0.81 ; \mathrm{h}_{15 \min } / \mathrm{h}_{30 \min }=0.70 ;$ $\mathrm{h}_{10 \min } / \mathrm{h}_{30 \min }=0.54 ; \mathrm{h}_{5 \min } / \mathrm{h}_{30 \min }=0.34$.

$P_{t}=\frac{h_{t}}{h_{t d}} \times P_{t d}$

In which: $\mathrm{P}_{\mathrm{t}}=$ rainfall depth of lower duration $(\mathrm{mm}) ; \mathrm{P}_{\mathrm{td}}=$ rainfall depth of higher duration; $\mathrm{h}_{\mathrm{t}} / \mathrm{h}_{\mathrm{td}}=$ derivation factor.

Finally, the IDF relationship where determined to each gauge station, using the model described by Equation 2:

$i=\left(a T^{b}\right)(t+c)^{-d}$

In which: $\mathrm{i}=$ average maximum rainfall intensity $\left(\mathrm{mm} \mathrm{h}^{-1}\right) ; \mathrm{T}=$ return period $($ year $) ; \mathrm{t}=$ rainfall duration (minutes) e a, b, c e d = local adjustment parameters.

The add-in program Solver (Microsoft Excel®) was used to adjust the parameters in order to minimize the sum of residuals between the values of average rainfall intensities estimated by the model and those observed. The fit quality was verified by the Nash-Sutcliffe coefficient and Camargo and Sentelhas (1997) performance coefficient.

Then, in possession of IDF relationships available in the literature and those adjusted in this study, the maximum average rainfall intensities were estimated for rain durations of 5-, 30, 60- and 120 minutes and 5 years return period. The estimated rainfall intensity values were spatially interpolated using ArcGIS software, applying the ordinary kriging interpolator.

Initially, an exploratory data analysis was performed, to verify data normality and the outliers. According to Naghettini and Pinto (2007), for an observation sample, an element is considered an outlier when it deviates significantly from all other points. To verify the outliers, the statistical tests Z-score, Grubbs and Beck and boxplot analysis were used.

After the exploratory analysis and removal of the outlier data, the theoretical semivariograms were adjusted using the Spherical, Exponential and Gaussian models. By means of cross-validation technique, the semivariogram model that provided the lowest standard errors among the values predicted by the model was verified, and it was employed in the rainfall intensity spatial interpolation. 


\section{RESULTS AND DISCUSSION}

The Gumbel's distribution fitted to the observed frequencies by the Kolmogorov-Smirnov test to 5\% significance for all the rainfall data employed in this study. Figure 1 shows the INMET-Lavras station IDF curves and the dispersion of the average rainfall intensities estimated by the Gumbel's distribution around the 1:1 line. A satisfactory adjustment of the IDF curve to the values estimated by the Gumbel's distribution is observed, with determination coefficients $\left(\mathrm{r}^{2}\right)$, Nash-Sutcliffe coefficient $\left(\mathrm{C}_{\mathrm{NS}}\right)$ and Camargo and Sentelhas performance coefficient (c) near to 1.0 and a low dispersion around the 1:1 line. This same behavior was verified in the IDF adjustments for the 4411 gauge stations used in this study.

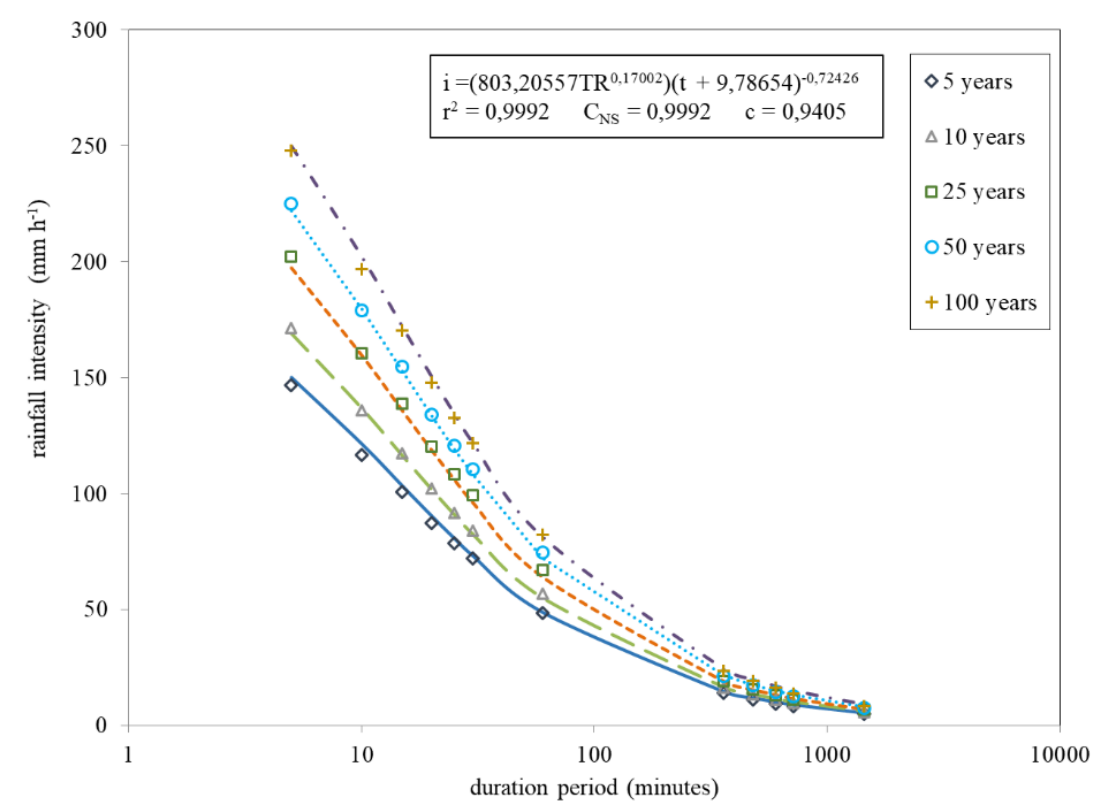

(a)

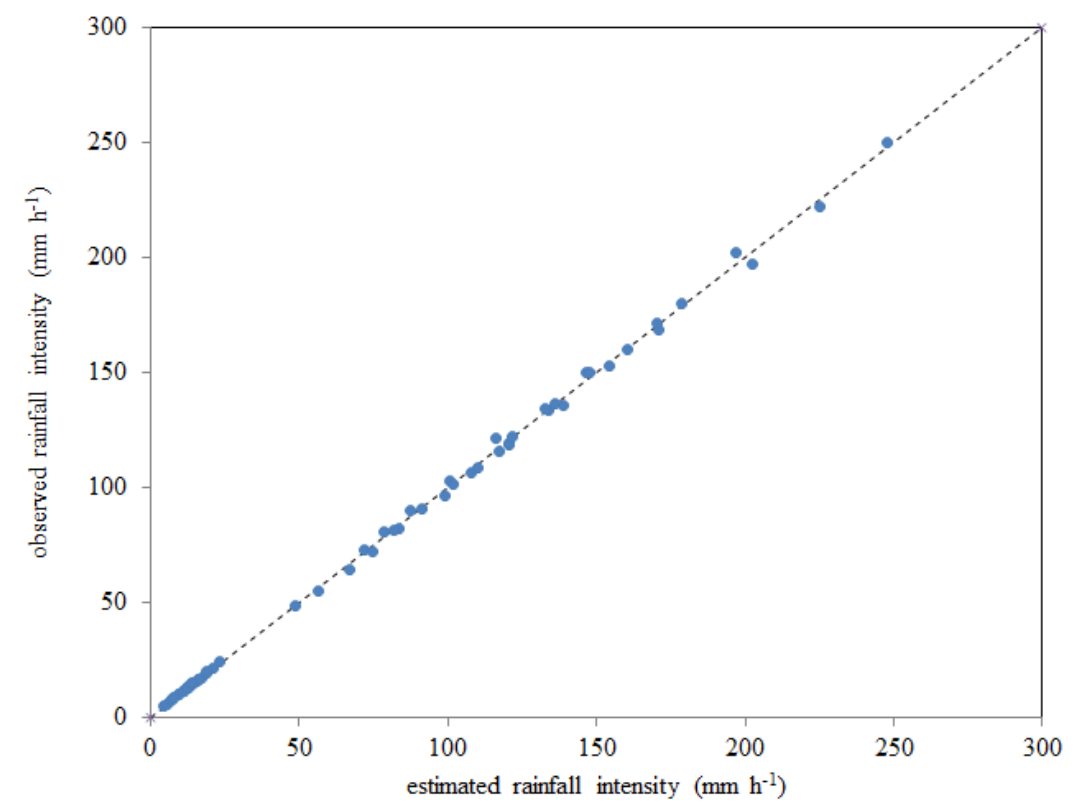

(b)

Figure 1. IDF curves for Lavras (a) and rainfall intensities dispersion estimated by Gumbel's distribution and predicted by the IDF relationship around the 1: 1 line (b). 
Analyzing the mean rainfall maximum intensities as a latitude and longitude function was verified a good data distribution around the average, characterizing unbiased data. Therefore, the conditions of the intrinsic hypothesis of geostatistics are met, so that rainfall intensities can be spatially interpolated.

The frequency histogram and the Quantil-Quantil (QQ) graphic of the maximum estimated precipitation for the 5-minute duration rainfall and 5-year return period are presented in Figure 2. According to Torman et al. (2012), the QQ chart can be used to evaluate the variable normality, and there will be a good data fitting to the normal distribution if the points are close to the reference line shown in the graph. Analyzing the histogram and the QQ graph, data normality was verified, and according to Mello et al. (2013) it is a desirable condition in geostatistics application in the data spatial interpolation. The rainfall intensity normality was also verified by the Anderson-Darling test at a 5\% significance level.
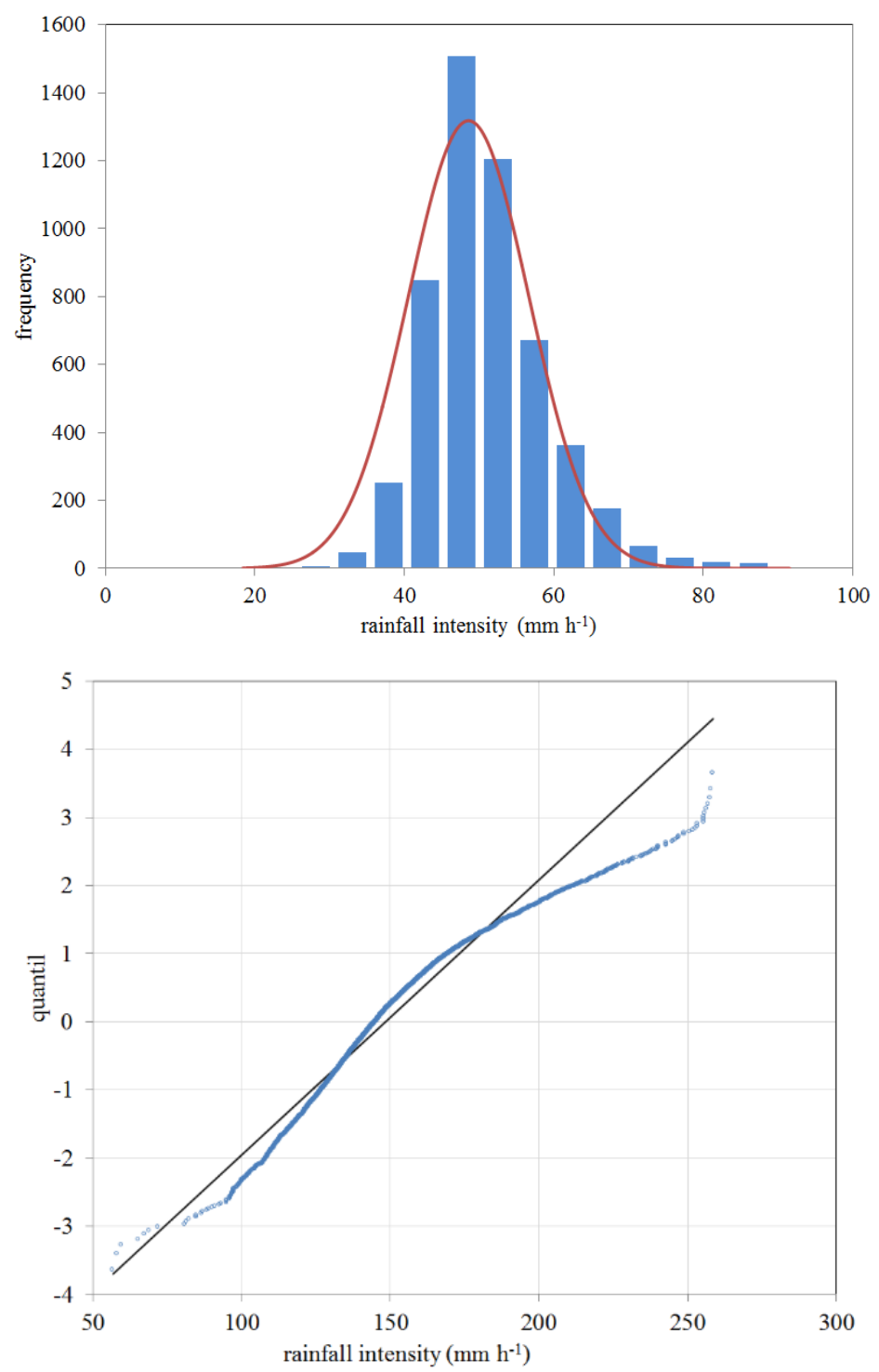

(b)

Figure 2. Frequency distribution for the duration of 60 minutes and the 5-year return period (a) and Quantil-Quantil graph (b) of the maximum average rainfall intensities estimated for the duration of 5 minutes and the 5-year return period. 
In Figure 2, it is observed that some rainfall intensity values are distanced from the theoretical normal distribution line. These points can represent observations results with gross errors or simply the manifestation of very rare events, which can be considered as outliers. Verifying the presence of outliers, the boxplot analysis was more sensitive in comparison to the other tests, with 194 stations (3.6\%), on average, classified with outliers for different rainfall durations.

Once the outliers were removed, the adjustments of the theoretical semivariograms models to the observed ones were analyzed. All the theoretical semivariogram models presented low values of the standardized mean errors (SME). For the Spherical model the value of SME was $-0.061 \%$; for the Exponential $-0.042 \%$ and for the Gaussian $-0.125 \%$ (Figure 3). In general, the Exponential model was the one that provided the lowest values of SME.

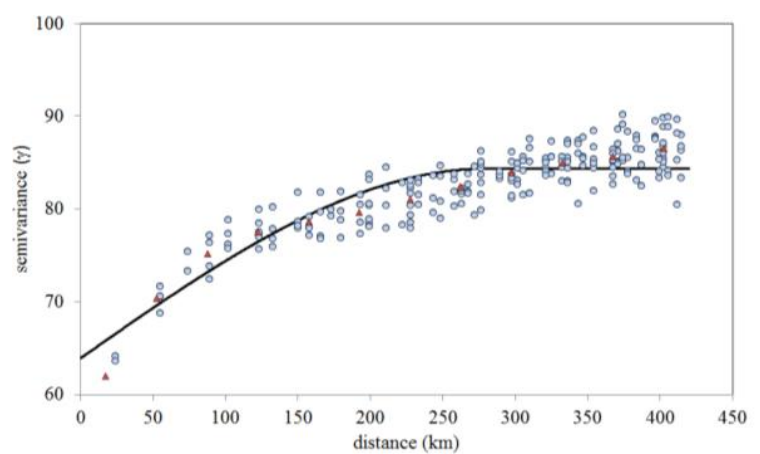

(a)

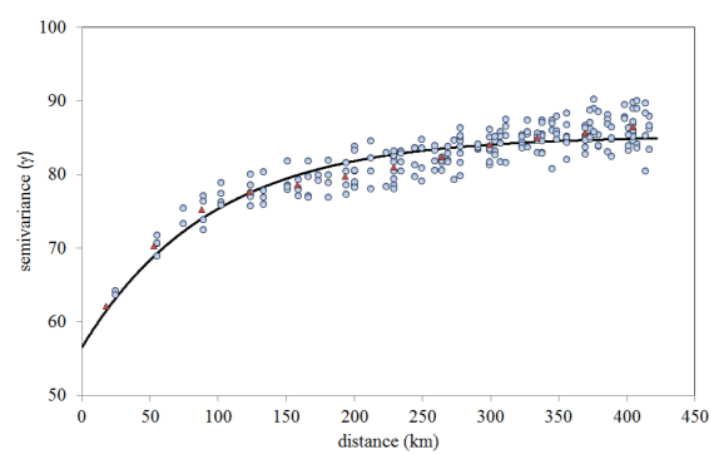

(b)

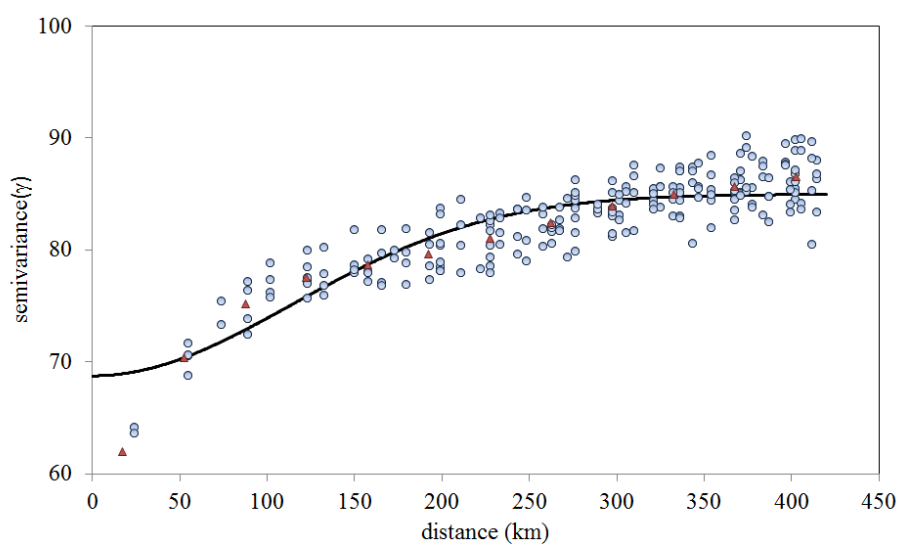

(c)

Figure 3. Experimental and theoretical semivariograms obtained by fitting the models (a) Spherical, (b) Exponential and (c) Gaussian for the duration of 30 minutes and 5 years return period.

Therefore, the thematic maps were generated by interpolation applying the ordinary kriging method and using the theoretical semivariogram adjusted by the Exponential model. In order to verify the quality values predicted by the interpolation, the dispersion of the predicted values in relation to the 1:1 line was analyzed. In the same way, the standard errors normality between rainfall intensities predicted by cross-validation and those estimated by the adjusted IDF curves were verified (Figure 4).

A linear trend of rainfall intensities predicted by cross-validation is observed in relation to those estimated by the adjusted IDF curves, with a reasonable data mass dispersion around the 1:1 line. The standardized errors among the rainfall intensity values predicted by crossvalidation and those estimated by the adjusted IDF relationships are normally distributed, which according to Mello et al. (2013) is a desirable condition in geostatistics. 


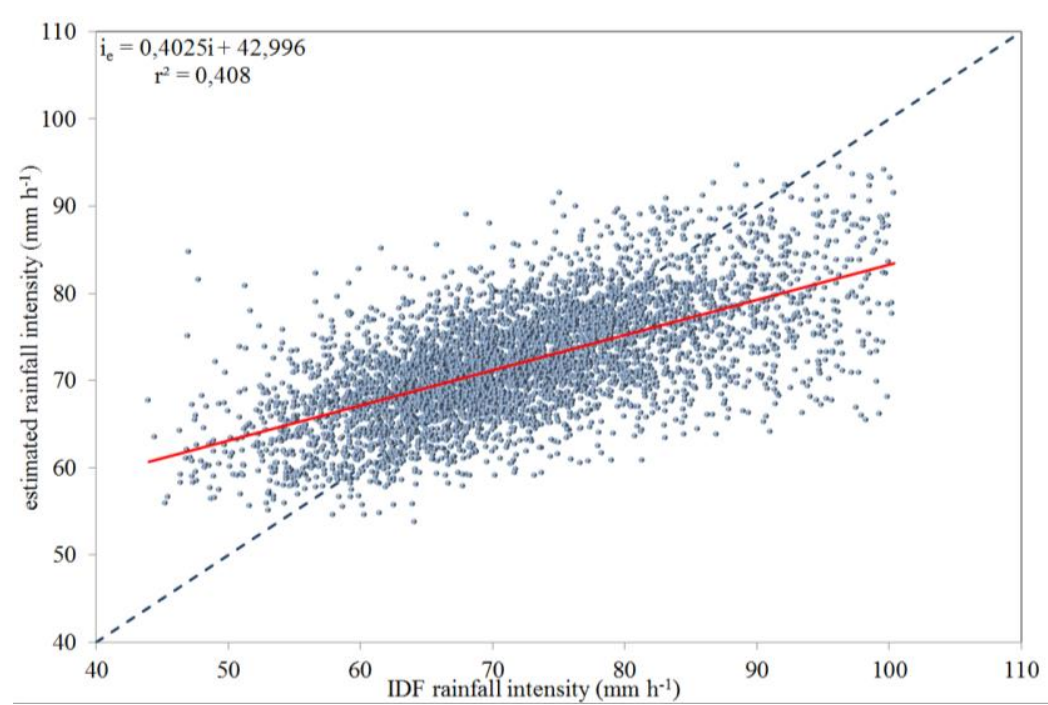

(a)

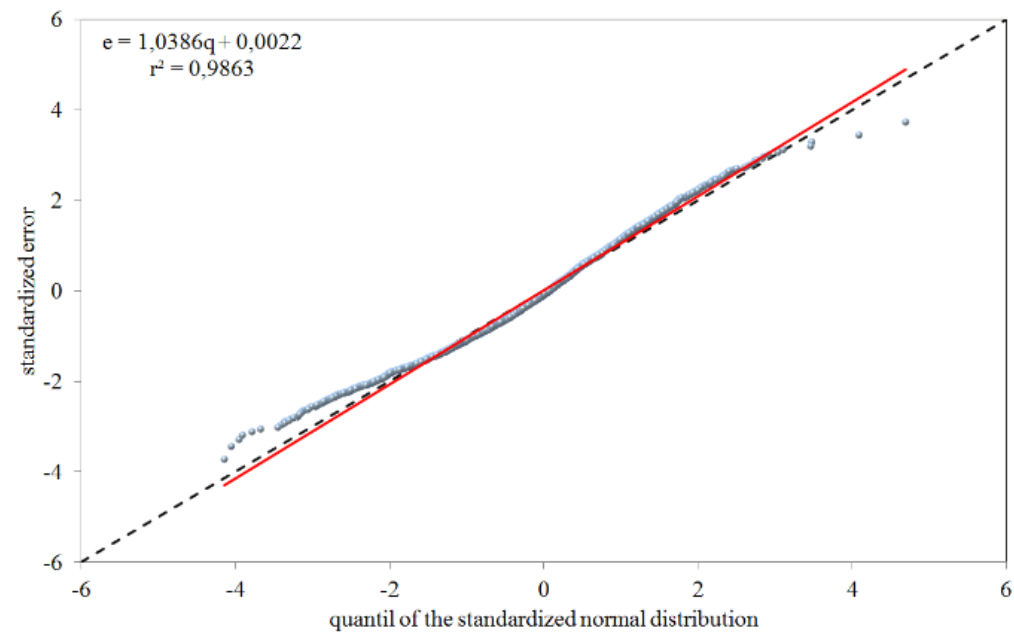

(b)

Figure 4. Maximum mean precipitation intensities estimated by cross-validation and obtained by IDF (a) and standard error obtained by using the exponential theoretical semivariogram model (b) for the duration of 5 minutes and 5 years return period.

Finally, the maximum average rainfall intensities thematic maps obtained for the durations of 5-, 30-, 60- and 120 minutes and 5-year return period are shown in Figure 5. According to the maps, there is a great variability of heavy rainfall in the Brazilian territory, with the highest values concentrated in the Amazon states and the southern region of the country. The lowest intensity rainfall values are concentrated in the semi-arid regions. This behavior is due to the atmospheric movement responsible for the formation of the convergence zones of the South Atlantic and Intertropical, which promote a contribution of air masses with high humidity favoring the rainfall formation.

The results obtained from the thematic maps are consistent with the work of Basso et al. (2016). The authors divided the Brazilian territory into homogeneous areas related to the heavy rainfalls, denominated isozones that consider the regional climatic behavior. These isozones obtained by Basso et al. (2016) have been preserved in the thematic maps created in this work, except for the Continental Isozone that involves a large part of the Amazon, the south of Piauí state and part of Goiás and Mato Grosso do Sul states. 

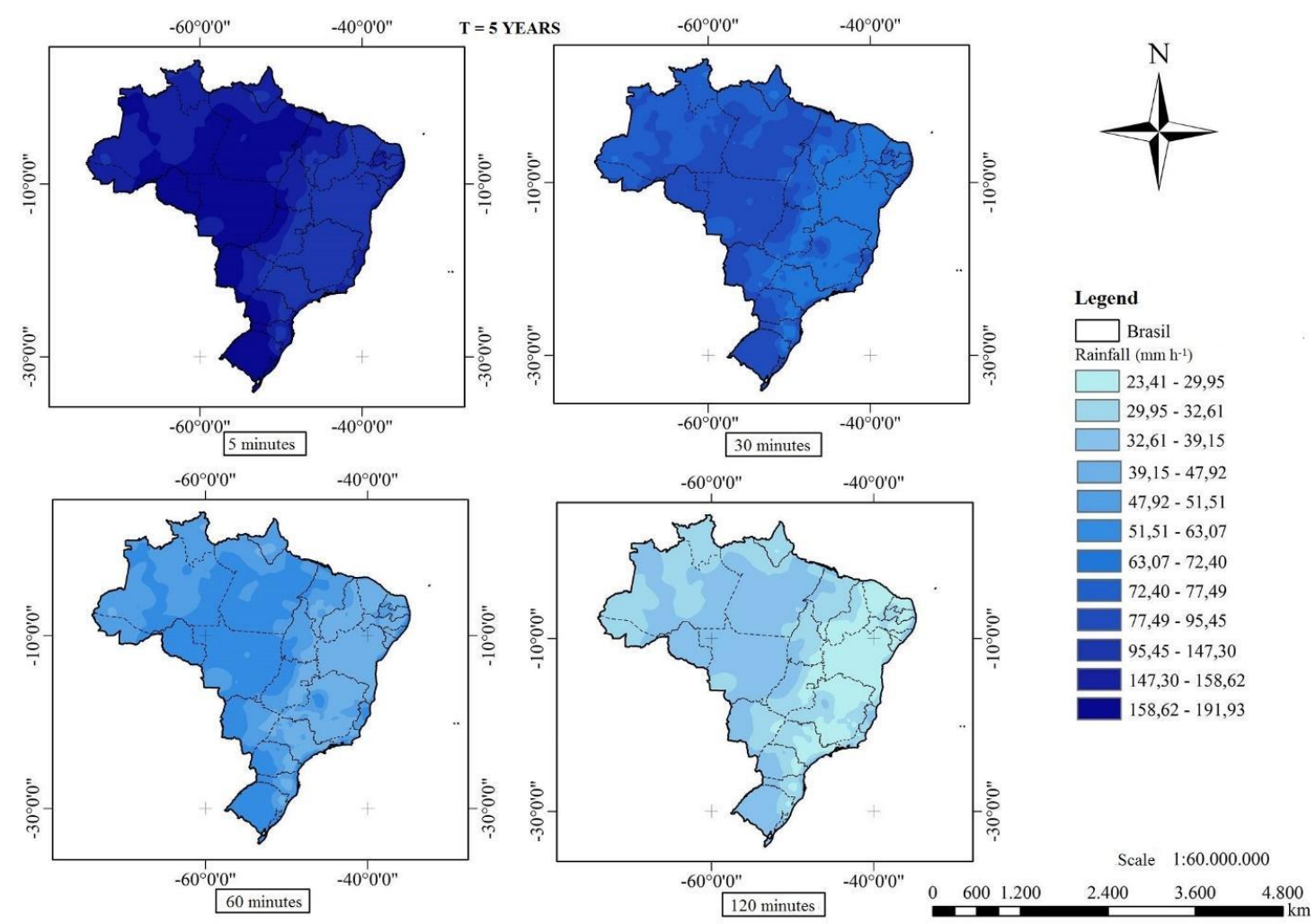

Figure 5. Heavy rainfall spatial distribution for the durations of 5-, 30-, 60- and 120 minutes and 5 years return period.

\section{CONCLUSIONS}

The methodology adopted to obtain IDF relationships was adequate, providing the creation of thematic maps of maximum rainfall intensities for durations of 5-, 30-, 60- and 120 minutes and return period of 5 years. Such maps allow obtaining rainfall values to design hydraulic structures such as flood control measures, representing a great tool for designers, mainly in locations lacking rainfall data.

\section{REFERENCES}

ALMEIDA, L. T. Espacialização de chuvas intensas: uma nova proposta. 2017. Dissertação (Mestrado) - Universidade Federal de Viçosa, Viçosa, 2017.

ARAGÃO, R.; SANTANA, G. R.; COSTA, C. E. F. F.; CRUZ, M. A. S.; FIGUEIREDO, E. E.; SRINIVASAN, V.S. Intense rainfall for the State of Sergipe based on disaggregated daily rainfall data. Revista Brasileira de Engenharia Agrícola e Ambiental, v. 17, p. 243-252, 2013. http://dx.doi.org/10.1590/S1415-4366201300030000

BACHIR, H.; SEMAR, A.; MAZARI, A. Statistical and geostatistical analysis related to geographical parameters for spatial and temporal representation of rainfall in semi-arid environments: the case of Algeria. Arabian Journal of Geosciences, v. 9, p. 486-498, 2016. https://doi.org/10.1007/s12517-016-2505-8

BASSO, R. E.; ALLASIA, D. G.; TASSI, R.; PICK BRENNER, K. Review of the high intensity rainfall zones of Brazil. Engenharia Sanitária Ambiental, v. 21, n. 4, p. 635 641, 2016. http://dx.doi.org/10.1590/s1413-41522016133691 
CALDEIRA, T. L.; BESKOW, S.; MELLO, C. R.; FARIA, L. C.; SOUZA, M. R.; GUEDES, H. A. S. Probabilistic modelling of extreme rainfall events in the Rio Grande do Sul state. Revista Brasileira de Engenharia Agrícola e Ambiental, v. 19, n. 3, p. 197-203, 2015. http://dx.doi.org/10.1590/1807-1929/agriambi.v19n3p197-203

CAMARGO, A. P.; SENTELHAS, P. C. Performance evaluation of different potential evapotranspiration estimating methods in the state of São Paulo, Brazil. Revista Brasileira Agrometeorologia, v. 5, n. 1, p. 89-97, 1997.

CAMPOS, A. R.; SANTOS, G. G.; SILVA, J. B. L.; IRENE FILHO, J.; LOURA, D. S. Intensity-duration-frequency equations for rainfall in the state of Piauí, Brazil. Revista Ciência Agronômica, v. 45, n. 3, p. 488-498, 2014. http://dx.doi.org/10.1590/S180666902014000300008

CAMPOS, A. R.; SANTOS, G. G.; ANJOS, J. C. R.; ZAMBONI, S. D. C.; MORAES, J. M. F. Rainfall intensity equations for the state of Maranhão, Brazil. Engenharia na Agricultura, v. 23, n. 5, p. 435-447, 2015.

CAMPOS, A. R.; SILVA, J. B. L.; SANTOS, G. G.; RATKE, R. L.; AQUINO, I. O. Estimate of intense rainfall equation parameters for rainfall stations in Paraiba state, Brazil. Pesquisa Agropecuária Tropical, v. 47, n. 1, p. 15-21, 2017. http://dx.doi.org/10.1590/1983-40632016v4743821

CARVALHO, J. R. P.; VIEIRA, S. R.; GREGO, C. R. Comparison of methods for adjusting semivariogram model of annual rainfall. Revista Brasileira de Engenharia Agrícola e Ambiental, v. 13, n. 4, p. 443-448, 2009. http://dx.doi.org/10.1590/S141543662009000400011

DAEE; CETESB. Drenagem urbana. 2. ed. São Paulo, 1980.

DENARDIN, J.; FREITAS, P. L. Fundamental characteristics of rainfall in Brazil. Pesquisa Agropecuária Brasileira, v. 17, n. 10, p. 1409-1416, 1982.

FRANCO, C. S.; MARQUES, R. F. P. V.; OLIVEIRA, L. F. C.; SILVA, A. M. Applicability and adjustment of the log-normal distribution to 3 parameters in the study of annual daily maximum precipitation in the Rio Verde basin. Revista da Universidade Vale do Rio Verde, v.1 6, p. 1-9, 2018.

LOUVET, S.; PATUREL, J. E.; MAHÉ, G.; ROUCHÉ, N.; KOITÉ, M. Comparison of the spatiotemporal variability of rainfall from four different interpolation methods and impact on the result of GR2M hydrological modeling — case of Bani River in Mali, West Africa. Theoretical and Applied Climatology, v. 123, p. 303-319, 2016. https://doi.org/10.1007/s00704-014-1357-y

MELLO, C. R. de; SILVA, A. M. da. Estimating methods of Gumbel probability distribution parameters and their influence on design hydrologic studies. Irriga, v. 10, n. 4, p. 318334, 2005.

MELLO, C. R.; VIOLA, M. R. Mapping of heavy rainfalls in the state of Minas Gerais. Revista

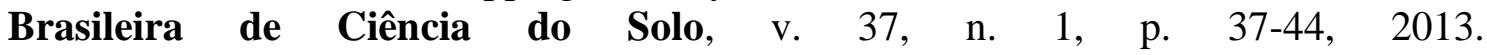
http://dx.doi.org/10.1590/S0100-06832013000100004

NAGHETTINI, M.; PINTO, E. J. A. Hidrologia estatística. Belo Horizonte: CPRM, 2007. $552 p$. 
OLIVEIRA, L. F. C.; CORTÊS, F. C.; WEHR, T. R.; BORGES, L. B.; SARMENTO, P. H. L.; GRIEBELER, N. P. Intensity-duration-frequency relationship of intensive rainfall for sites in goiás state and federal district. Pesquisa Agropecuária Tropical, v. 35, n. 1, p. 18-18, 2005.

OLIVEIRA, L. F. C.; VIOLA, M. R.; PEREIRA, S.; MORAIS, N. R. Intense rainfall prediction models for the state of Mato Grosso, Brazil. Revista Ambiente \& Água, v. 6, n. 3, p. 274-290, 2011. http://dx.doi.org/10.4136/ambi-agua.553

PFAFSTETTER, O. Chuvas intensas no Brasil. Rio de Janeiro: DNOS, 1957. 246 p.

PENNER, G.C.; LIMA, M. P. Comparação entre métodos de determinação da equação de chuvas intensas para a cidade de Ribeirão Preto. Geociências, v. 35, n. 4, p. 542-559, 2016.

RIGHI, E.; BASSO, L. A. Application and analysis of interpolation techniques for spatialization of rainfall. Ambiência, v. 12, n. 1, p. 101-117, 2016.

SANTOS, G. G.; FIGUEIREDO, C. C.; OLIVEIRA, L. F. C.; GRIEBELER, N. P. Intensityduration-frequency of rainfall for the State of Mato Grosso do Sul. Revista Brasileira de

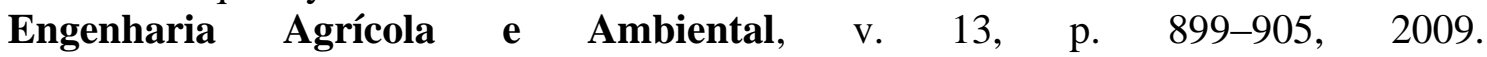
http://dx.doi.org/10.1590/S1415-43662009000700012

SILVA, C. B.; OLIVEIRA, L. F. C. Intensity-duration-frequency relation of extreme rains in the northeastern region of Brazil. Revista Brasileira de Climatologia, v. 20, n. 13, p. 267-283, 2017.

SILVA MIRANDA, C. T.; THEBALDI, M. S.; ROCHA, G. M. B. Annual daily maximum rainfall and estimate of intense rain equation for the Divinópolis municipality, MG, Brazil. Revista Scientia Agraria, v. 18, n. 4, p. 9-16, 2017. http://dx.doi.org/10.5380/rsa.v18i4.49883

SOUZA, R. O. R. M.; SCARAMUSSA, P. H. M.; AMARAL, M. A. C. M.; PEREIRA NETO, J. A.; PANTOJA, A. V.; SADECK, L. W. R. Intense rainfall equations for the State of Pará, Brazil. Revista Brasileira de Engenharia Agrícola e Ambiental, v. 16, n. 9, p. 999-1005, 2012. http://dx.doi.org/10.1590/S1415-43662012000900011

TORMAN, V. B. L.; COSTER, R.; RIBOLDI, J. Normalidade de variáveis: métodos de verificação e comparação de alguns testes não-paramétricos por simulação. Revista HCPA, v. 32, n. 2, p. 227-234, 2012.

XAVIER, A. C.; CECÍllO, R. A.; PRUSKI, F. F.; LIMA, J. S. S. Methodology for spatialization of intense rainfall equation parameters. Engenharia Agrícola, v. 34, n. 3, p. 485-495, 2014. http://dx.doi.org/10.1590/S0100-69162014000300012 